\title{
Sosialisasi Pencegahan Covid-19 Melalui Penggunaan Bahasa Kamaru
}

\author{
Azaz Akbar $^{1 \bowtie}$ Irwan $^{2}$, Kamarudin $^{3}$, Agusalim $^{4}$, Hijrawatil Aswat $^{5}$, Sanufi $^{6}$ \\ Pendidikan Guru Sekolah Dasar, Universitas Muhammadiyah Buton, Indonesia ${ }^{1,2,3,4,5}$ \\ Bahasa dan Sastra Indonesia, Universitas Hasanudin, Indonesia ${ }^{6}$ \\ E-mail: azaz.akbar23@gmail.com ${ }^{1}, \underline{\text { irwanlatif19@gmail.com }}{ }^{2}, \underline{\text { akamarudin15@gmail.com }}^{3}$, \\ agusumbuton@gmail.com ${ }^{4}$, hijrawatil171208@gmail.com ${ }^{5}, \underline{\text { sanufi.sanu12@gmail.com }}^{6}$
}

\begin{abstract}
Abstrak
Tingginya angka penularan Covid-19 dan semakin rendahnya penutur Bahasa Kamaru menjadi salah satu pertimbangan pemilihan topik yang digunakan dalam kegiatan sosialisasi. Keadaan ini dipertegas dengan pentingnya peran pemerintah dan Lembaga Swadaya Masyarakat (LSM) dan penyelenggara Pendidikan Tinggi dalam upaya sosialisasi pencegahan Covid-19 dari tingkat kota sampai tingkat desa. Metode pelaksanaan kegiatan ini dilakukan dengan penyebaran brosur berupa himbauan kepada masyarakat melalui beberapa media seperti Facebook dan WhatsApp. Kegiatan pengabdian ini mensosialisasikan pencegahan Covid-19 dengan menyampaikan beberapa informasi untuk merubah kebiasaan, mengenali gejala Covid-19, mengenali tempat rawan terpapar Covid-19, juga membentuk kebiasaan untuk mencuci tangan menggunakan sabun, menjaga jarak, dan menggunakan masker dengan menyebarkan brosur baik dari media berupa WhatsApp, Facebook, dan pamflet yang disebarkan di desa penutur bahasa Kamaru. Pengabdian ini mendapat respon baik dari beberapa kalangan.
\end{abstract}

Kata kunci: sosialisasi, Covid-19, bahasa daerah Kamaru

Abstract

The high rate of Covid-19 transmission and the lowering of Kamaru language speakers are one of the considerations for selecting topics used in socialization activities. This situation is emphasized by the importance of the role of the Government and Non-Governmental Organizations (NGOs) and higher education providers in socializing the prevention of Covid-19 from the city to the village level. The method of implementing this activity was carried out by distributing brochures in the form of appeals to the public through several media such as Facebook and WhatsApp. This service activity socializes the prevention of Covid-19 by delivering some information to change habits, recognize the symptoms of Covid-19, recognize places prone to exposure to Covid-19, also form the habit of washing hands using soap, keeping distance, and using masks by distributing good brochures from media in the form of WhatsApp, Facebook, and pamphlets distributed in the village of Kamaru language speakers. This service received a good response from several circles.

Keywords: socialization, Covid-19, Kamaru regional language

Copyright (c) 2021 Azaz Akbar, Irwan, Kamarudin Agusalim, Hijrawatil Aswat, Sanufi

$\triangle$ Corresponding author

Address : Jln. Betoambari No. 36 Kota Baubau

Email : azaz.akbar23@gmail.com

DOI : https://doi.org/10.31004/abdidas.v2i3.302

ISSN 2721- 9224 (Media Cetak)

ISSN 2721- 9216 (Media Online) 
460 Sosialisasi Pencegahan Covid-19 Melalui Penggunaan Bahasa Kamaru- Azaz Akbar, Irwan, KamarudinAgusalim, Hijrawatil Aswat, Sanufi

DOI: https://doi.org/10.31004/abdidas.v2i3.302

\section{PENDAHULUAN}

Covid-19 seketika menjadi perhatian berbagai negara, tidak terkecuali Indonesia. Data Kementerian Kesehatan Indonesia, kasus Covid-19 di Wuhan terjadi pada tanggal 30 Desember 2019. Saat itu, Wuhan Municipal Health Committee mengeluarkan pernyataan "urgent notice on the treatment of pneumonia of unknown cause" (Hanoatubun, 2020).

Dengan atau tanpa Covid-19, kita semua sependapat bahwa perubahan terus terjadi. Hal ini memaksa kita untuk memetik remah-remah dari setiap peristiwa yang terjadi. Kemajuan teknologi informasi sudah membawa pengaruh terhadap kehidupan masyarakat. Sejak penemuan komputer tahun 1955, peradaban dunia sudah memasuki era informasi. Teknologi informasi dengan komputer menjadi motor penggerak dan mengubah segalanya (Maharsi et al., 2020).

Berdasarkan edaran di Lingkungan Kemendikbud No. 2 Tahun 2020 tentang Pencegahan dan Penanganan Covid-19 bahwa penyelenggaraan pendidikan dan pembelajaran dilaksanakan secara daring (Alami, 2020). Pada sisi yang lain, keadaan yang menunjukkan kepunahan bahasa-bahasa daerah menjadi fenomena yang cukup menarik perhatian banyak kalangan ilmuwan terutama para linguistik (Tondo, 2009). Menurut SIL (2001), banyak bahasa daerah, termasuk Jawa $\quad(75.200 .000$ penutur), Sunda (27.000.000 penutur), Melayu (20.000.000 penutur), dan Madura (13.694.000 penutur), Minangkabau (6.500.000 penutur), Batak (5.150.000 penutur), Bugis (4.000.000 penutur), dan bahasa Bali (3.800.000 penutur), bahasa Aceh
(3.000.000 penutur), Sasak (2.100.000 penutur), Makassar (1.600.000 penutur), bahasa Lampung (1.500.000 penutur), dan Rejang (1.500.000 penutur) adalah bahasa penutur bahasa Aceh (1.000.000 penutur) dilaporkan memiliki jumlah pengguna terbesar, juga melebihi satu juta (Sobarna, 2007).

Bahasa Kamaru adalah satu jenis bahasa yang penuturnya berasal dari daerah terkecil Kecamatan Lasalimu, Kabupaten Buton, Provinsi Sulawesi Tenggara. Penutur Bahasa kamaru terdiri dari masyarakat Desa Suandala, Desa Togo Mangura, Desa Sribatara, sebagian masyarakat Kelurahan Kamaru, masyarakat Desa Bonelalo, dan sebagian masyarakat Wasuamba dan Wasamba.

Pandemi Covid-19 sejatinya adalah wabah baru, tetapi jika kita melihat jauh kebelakang ternyata juga terjadi peristiwa yang hampir sama yakni mewabahnya virus Kolera. Tetapi dengan wabah ini, lahir sebuah novel yang cukup menarik dengan judul Love In The Time Of Cholera karangan Gabriel Garcia Marquez pada tahun 1985 yang juga dijadikan film pada tahun 2007 (Edwards et al., 1991).

Dengan demikian, maka seyogyanya dampak yang bisa kita gunakan dalam meningkatkan penggunaan bahasa daerah dengan menyiarkan informasi pencegahan Covid-19 dengan bahasa daerah. Ketakutan masyarakat akan virus ini akan menjadi pendorong masyarakat untuk berupaya menggali informasi terkait corona dengan berbagai sumber, termaksud yang bersumber dari bahasa daerah Kamaru. 
461 Sosialisasi Pencegahan Covid-19 Melalui Penggunaan Bahasa Kamaru- Azaz Akbar, Irwan, KamarudinAgusalim, Hijrawatil Aswat, Sanufi

DOI: https://doi.org/10.31004/abdidas.v2i3.302

Kita semua ingin menjaga dan membela negara Indonesia dari serangan Covid-19, maka perlu untuk saling mengingatkan, menasihati agar sama-sama menerapkan protokol kesehatan Covid19 yaitu dengan senantiasa membersihkan tangan menggunakan sabun dan air yang mengalir atau handsanitizer, menjaga jarak minimal 1 meter, dan selalu menggunakan masker ketika keluar rumah (bepergian). Hal ini penting dilakukan dalam rangka mengurangi risiko terjadinya penularan Covid-19 (Prayitno et al., 2020).

Protokol kesehatan Covid-19 dapat dilaksanakan dengan baik bila pemerintah pusat, pemerintah daerah, dan semua elemen bekerjasama mensosialisasikan kepada masyarakat bawah untuk menjalankan protokol kesehatan yang diberlakukan oleh pemerintah untuk keselamatan bersama, karena masyarakat bawah masih banyak yang belum memahami sehingga mengabaikan protokol kesehatan Covid-19. Sosialisasi ini dianggap cukup penting karena penyebaran Covid19 masih sangat cepat yang menular melalui mulut, hidung dan mata manusia jika terjadi kontak langsung. (Syafrida \& Hartati, 2020).

Kegiatan sosialisasi ini dilakukan dalam rangka membantu program pemerintah dalam mengurangi penyebaran Covid-19 di Indonesia. Kegiatan ini juga setidaknya membangun kembali kesadaran masyarakat penutur bahasa Kamaru untuk mencintai bahasa daerah dengan menjaga kelestariannya.

\section{METODE}

Sosialisasi pencegahan Covid-19 melalui penggunaan bahasa Kamaru dilaksanakan pada tanggal 20 Agustus 2020 pada beberapa media seperti Facebook dan WhatsApp.

Kegiatan sosialisasi pencegahan Covid-19 melalui penggunaan bahasa Kamaru dilaksanakan dengan menyebarkan brosur berupa himbauan kepada masyarakat melalui beberapa media seperti Facebook dan WhatsApp, juga disebarkan pada beberapa sekolah yang ada di Kabupaten Buton. Adapun tahapan kegiatanya yaitu

1. Tahap perencanaan: menyediakan konsep yang digunakan dalam mensosialisasikan pencegahan Covid-19 dengan bahasa Kamaru, bersama dengan pemangku kepentingan membuat persetujuan program dan kesepakatan untuk dukungan kegiatan, dan mengumpulkan beberapa materi untuk dijadikan pamflet sosialisasi.

2. Tahap pelaksanaan kegiatan: mengalihkan pamflet sosialisasi pencegahan Covid-19 dari bahasa Indonesia ke dalam bahasa Kamaru, menyebarkan brosur pada beberapa media seperti Facebook dan WhatsApp, dan pembagian brosur pada beberapa tempat yang sering dilalui masyarakat.

\section{HASIL DAN PEMBAHASAN}

Kegiatan pengabdian ini dilakukan dalam rangka menjalankan Tri Dharma Perguruan Tinggi sebagai dosen, yaitu melakukan pengajaran, penelitian, dan pengabdian kepada masyarakat. Pengabdian tentang sosialisai pencegahan Covid19 dengan bahasa Kamaru dilakukan dengan beberapa pendekatan yakni penyebaran informasi melalui media Facebook dan WhatsApp juga 
462 Sosialisasi Pencegahan Covid-19 Melalui Penggunaan Bahasa Kamaru- Azaz Akbar, Irwan, KamarudinAgusalim, Hijrawatil Aswat, Sanufi

DOI: https://doi.org/10.31004/abdidas.v2i3.302

penyebaran brosur pada beberapa tempat yang sering dilalui masyarakat.

Pengabdian ini, ada beberapa tahapan yang telah dilakukan terdiri tahap perencanaan dan pelaksanaan. Tahap perencanaan dilakukan untuk mempersiapkan instrumen dalam mendukung program pengabdian yang terdiri dari beberapa brosur mentah yang dibuat oleh Satuan Tugas Penanganan Covid-19 untuk dialihbahasakan ke dalam bahasa daerah Kamaru.

Langkah selanjutnya adalah pelaksanaan. Pada tahapan ini ada beberapa hal yang dilakukan yang terdiri dari; pertama: alih bahasa, kedua: menyebarkan pada beberapa media informasi baik Facebook maupun WhatsApp.

Berikut beberapa gambar keterangan proses pengabdian yang telah dilakukan:

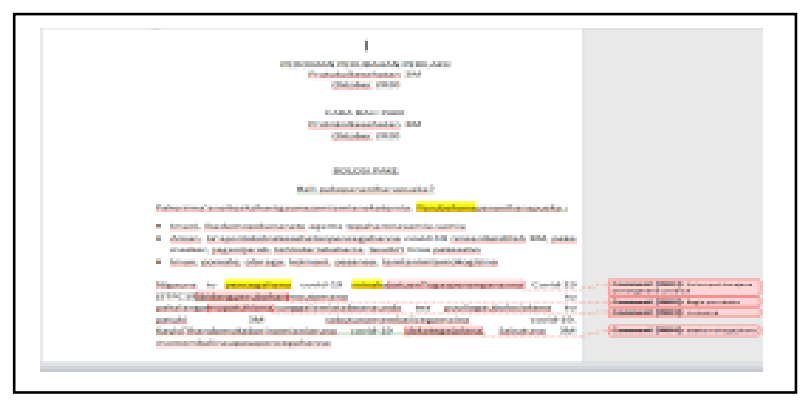

Gambar 1. Data Mentah Hasil Alih Bahasa

Gambar di atas merupakan data mentah yang sedang dialih bahasakan dari bahasa Indonesia ke dalam Bahasa Kamaru. Data mentah ini diambil dari Satgas Covid-19.

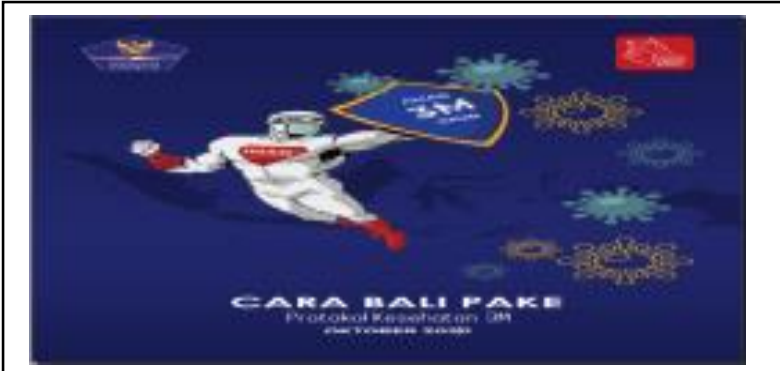

Gambar 2. Tampilan Depan Brosur Sosialisasi

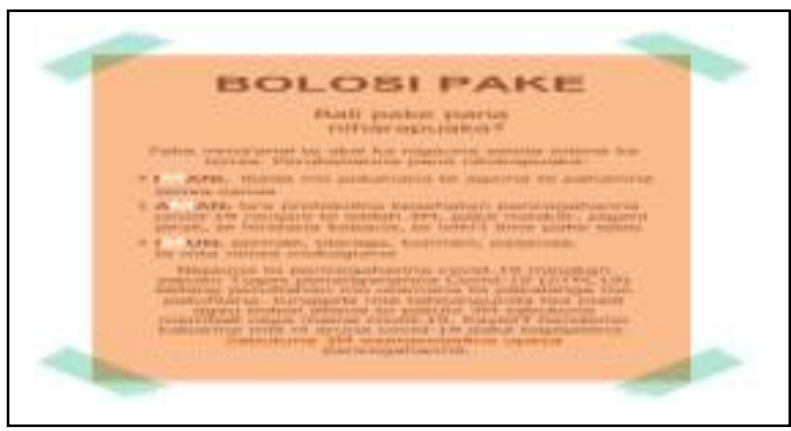

Gambar 3. Himbauan Merubah Kebiasaan

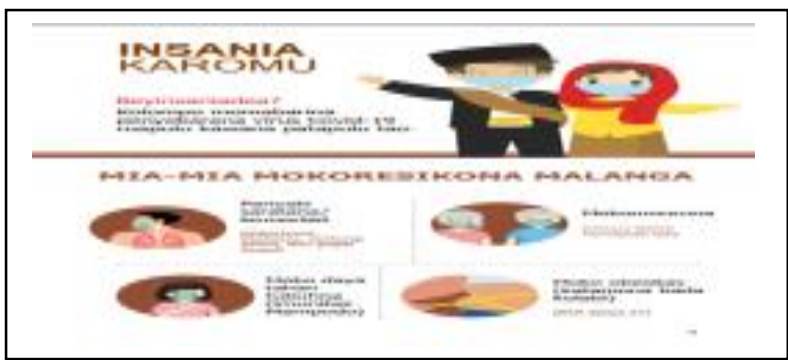

Gambar 4. Himbauan Mengenal Gejala

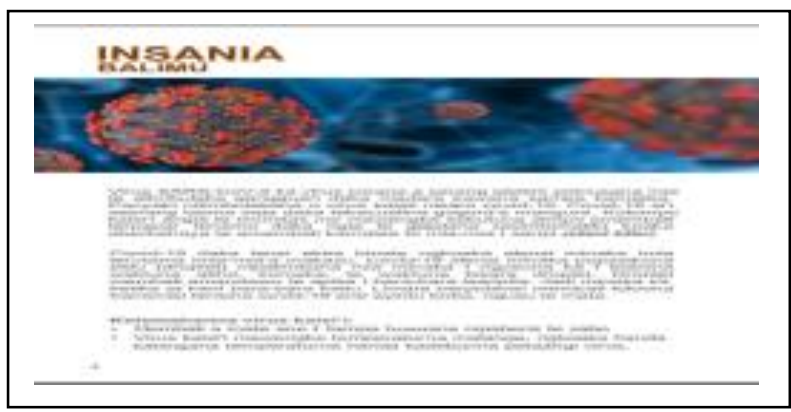

Gambar 5. Himbauan Mengenali Musuh (Covid-

19) 
463 Sosialisasi Pencegahan Covid-19 Melalui Penggunaan Bahasa Kamaru- Azaz Akbar, Irwan, KamarudinAgusalim, Hijrawatil Aswat, Sanufi

DOI: https://doi.org/10.31004/abdidas.v2i3.302

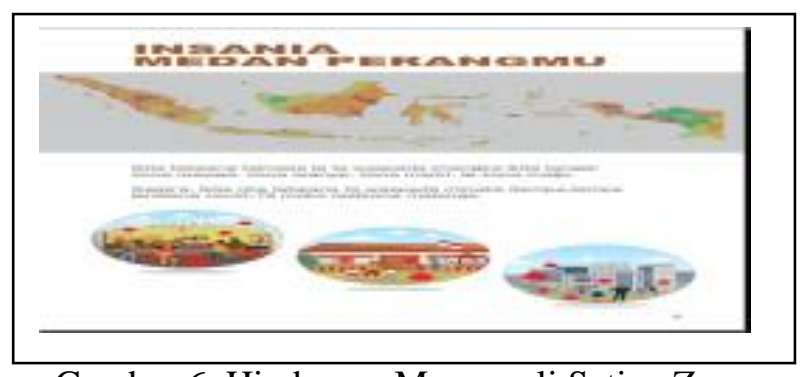

Gambar 6. Himbauan Mengenali Setiap Zona

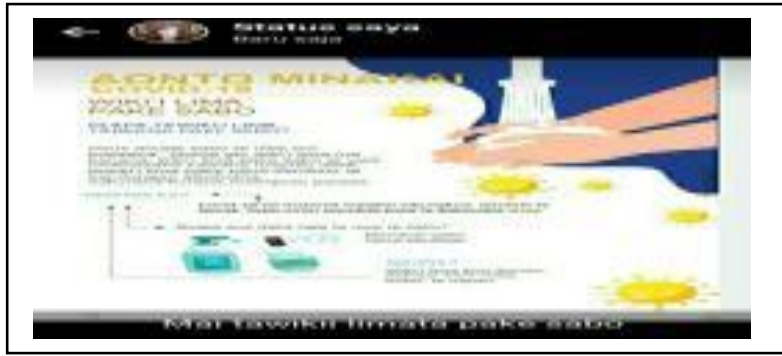

Gambar 8. Sosialisasi Melalui Whatshap

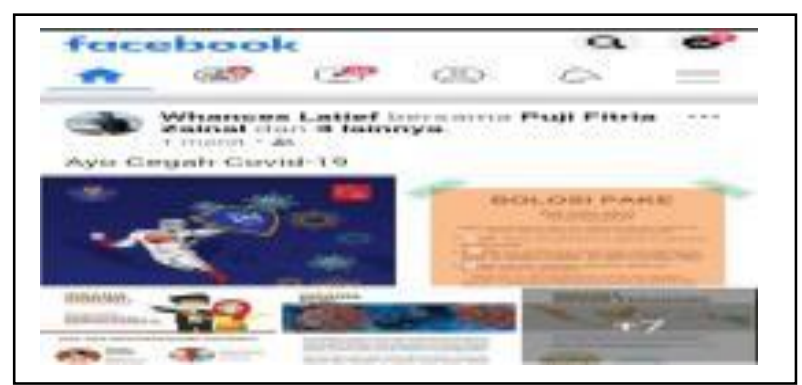

Gambar 9. Sosialisasi Melalui Facebook

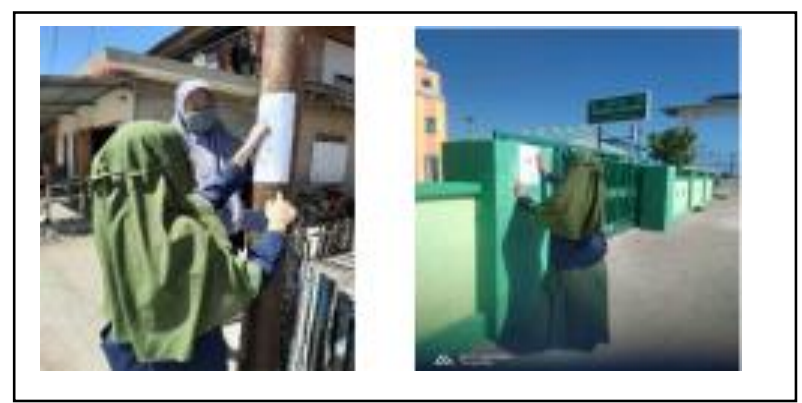

Gambar 10. Pemasangan Brosur di Pedesaan

Gambar 2 sampai pada gambar 7 merupakan brosur informasi pencegahan Covid-19 dengan menggunakan bahasa Kamaru. Brosur ini merupakan gambar jadi dari tim Satgas Covid-19 yang dialihbahasakan ke dalam bahasa Kamaru yang sekiranya mengandung unsur-unsur yang mengedukasi masyarakat untuk menekan laju penyebaran Covid-19 dengan mengenali gejala Covid-19, menghindari kerumunan, merubah kebiasaan lama, mengenal gejala Covid-19, dan menghindari tempat-tempat yang merupakan zona merah yang berpotensi tinggi terhadap penyebaran Covid-19.

Gambar 8 merupakan hasil tangkapan layar dari sosialisasi yang menggunakan media berupa WhatsApp, sedangkan pada gambar 9, merupakan hasil tangkapan sosialisasi dengan menggunakan media berupa Facebook. Terakhir pada gambar10 merupakan gambar kegiatan pemasangan brosur/pamflet pada beberapa titik umum yang sering dilalui penutur bahasa Kamaru.

\section{SIMPULAN}

Kegiatan sosialisasi pencegahan Covid-19 dengan menggunakan bahasa Kamaru berjalan dengan baik. Terlaksanaanya sosialisasi ini membangun kesadaran kepada masyaraat penutur bahasa Kamaru untuk terus menekan laju penyebaran Covid-19, sekaligus membangun kesadaran untuk terus melestarikan bahasa Kamaru.

\section{UCAPAN TERIMA KASIH}

Terima kasih kami ucapkan kepada Rektor Universitas Muhammadiyah Buton yang senantiasa mendukung jalannya program Tri Dharma yang kami lakukan. Hingga pada akhirnya, ucapan terima kasih kami sampaikan kepada semua pihak yang sudah ikut terlibat dalam pelaksanaan kegiatan ini. 
464 Sosialisasi Pencegahan Covid-19 Melalui Penggunaan Bahasa Kamaru- Azaz Akbar, Irwan, KamarudinAgusalim, Hijrawatil Aswat, Sanufi

DOI: https://doi.org/10.31004/abdidas.v2i3.302

\section{DAFTAR PUSTAKA}

Alami, Y. (2020). Media Pembelajaran Daring pada Masa Covid-19 Online Learning Media during the Coronavirus Disease. JPAI, 2(1).

Edwards, S., Moennig, V., \& Wensvoort, G. (1991). The development of an international reference panel of monoclonal antibodies for the differentiation of hog cholera virus from other pestiviruses. Veterinary Microbiology. https://doi.org/10.1016/0378-1135(91)90118Y

Hanoatubun, S. (2020). Dampak COVID-19 Terhadap Perekonomian Indonesia. Journal of Education, Psychology and Counseling, 2(1).

Maharsi, S., Handayani, O. W. K., \& Wijayanti, Y. (2020). Efectivity Evaluation among Dengue Control Programs in Semarang City, Indonesia. Unnes Journal of Public Health, 9(2).

https://doi.org/10.15294/ujph.v9i2.37512

Prayitno, S. A., Pribadi, H. P., \& Ifadah, R. A. (2020). PERAN SERTA DALAM MELAKSANAKAN PROTOKOL PENCEGAHAN PENYEBARAN CORONA VIRUS DISEASE (COVID-19) PADA MASYARAKAT. DedikasiMU(Journal of Community Service). https://doi.org/10.30587/dedikasimu.v2i3.165 7

Sobarna, C. (2007). BAHASA SUNDA SUDAH DI AMBANG PINTU KEMATIANKAH? Makara Human Behavior Studies in Asia. https://doi.org/10.7454/mssh.v11i1.39

Syafrida, S., \& Hartati, R. (2020). Bersama Melawan Virus Covid 19 di Indonesia. SALAM: Jurnal Sosial Dan Budaya Syar-I. https://doi.org/10.15408/sjsbs.v7i6.15325

Tondo, F. H. (2009). Kepunahan Bahasa-Bahasa Daerah: Faktor Penyebab Dan Implikasi Etnolinguistis. Jurnal Masyarakat \& Budaya. 